\title{
Acantholytic Dermatosis of the Vulva: Case Series and Review of Literature
}

\author{
Shereen Zia, Mohamed Alhamar and Adrian Ormsby* \\ Department of Pathology and Lab Medicine, Henry Ford Health System, USA
}

Submission: July 10, 2020; Published: July 17, 2020

*Corresponding author: Adrian Ormsby, Department of Pathology and Lab Medicine, Henry Ford Health System, Detroit, USA

\begin{abstract}
Papular Acantholytic dyskeratosis; also known as acantholytic dermatosis of the vulvocrural area, is a rare inflammatory disorder of the genital location. This review discusses the clinical and pathologic correlation of this rare entity, its differential diagnosis and a recent case series with analysis of all previous reported cases in the literature.
\end{abstract}

Keywords: Acantholytic Dermatosis; Dyskeratosis; Acantholysis Papular Acantholytic Dyskeratosis

\section{Introduction}

Papular Acantholytic dyskeratosis; also known as acantholytic dermatosis of the vulvocrural area, is a rare but distinct histopathologic cutaneous disorder of the genitalia which was first described as a subset of focal acantholytic dyskeratosis in 1972 and can present with a variety of clinical manifestations. This review discusses the clinical and pathologic presentation of this entity and its differential diagnosis as well asreview of literature.

\section{Case Series}

The first case is a 72 year old African American woman; post-hysterectomy, came with the complaint of pruritus on the medial aspect of left labia majora. The patient's most recent pap smear was normal and she denied any associated discharge or post-menopausal vaginal bleeding. Physical examination showed a slightly raised, grayish lesion, measuring $5 \mathrm{~mm}$ on the medial aspect of the left labia majora with normal external genitalia, no adnexal masses or tenderness, no bladder tenderness, and an unremarkable rectovaginal septum. Clinical considerations included vulvar dystrophy and condyloma. Excisional biopsy was obtained. Histologic examination found acantholysis with dyskeratotic keratinocytes and associated chronic inflammation (Figures 1 \& 2). Periodic acid-Schiff (PAS) stainwas negative for fungi. HSV1 immunostain was negative. There was no personal or family history of Hailey-Hailey or Darier's disease. There was no associated skin rash or dermatologic papules and vesicles in the axilla, central chest or trunk. Microscopy did not show any dysplasia or atypi cal mitoses. The clinical features personal and family history and microscopic findings were diagnostic of acantholytic dermatosis. A second case is a 44 year old Caucasian woman who presented with a single asymptomatic, skin colored, solitary papule, measuring $4 \mathrm{~mm}$ on the vulva. The patient reported no pruritic or papulovesicular lesions elsewhere on the body with no associated personal or family history of Hailey-Hailey or Darier's disease. The lesion was surgically excised and submitted for routine pathologic evaluation. On microscopic examination, the sections showed hypergranulosis, focal acantholysis and dyskeratotic keratinocytes. HSV1 immunostain was negative and PAS stain did not demonstrate fungal organisms. The clinical features, personal and family history and microscopic findings were diagnostic of acantholytic dermatosis (Figures $3 \& 4$ ).

\section{Discussion}

Acantholytic dermatosis of the vulva has been regarded as a subset of focal acantholytic dyskeratosis; a term first proposed by Ackerman in 1972 [1]. Papular acantholytic dyskeratosis has been reported as a distinct histopathologic entity which can present with varying clinical manifestations. The common sites of occurrence are vulva, penis, scrotum, perianal area, and inguinal folds. A rare case involving vaginal epithelium has also been reported [2]. Clinical presentation ranges from solitary, discrete lesion to multiple grouped or confluent, flesh-colored papules, vesicles and bullae as well as white macerated patches and plaques [3]. The involved area is generally asymptomatic, but pruritis, erythema 
and burning has also been noted [4]. It has a chronic course and shows variable response to different treatment options including; topical retinoids, steroids, cryotherapy, electrocoagulation, laser therapy and surgery [5]. Histologically, intraepidermal acantholysis is seen, along with dyskeratosis including corps ronds and grains. Other histologic findings include parakeratosis, hyperker- atosis, suprabasal cleft formation and corp ronds (dyskeratotic cells composed of basophilic nucleus with a perinuclear halo and eosinophilic cytoplasm) and corp grains (small cells with elongated, hyperchromatic nuclei in stratum corneum and granulosum) in the acantholytic layer of the epidermis2 3. Direct Immunofluorescence consistently shows negative results.


Figure 1 \& 2: (10X) and (40X) Hematoxylin-eosin stain showing focal acantholysis, and dyskeratotic keranitnocytes.
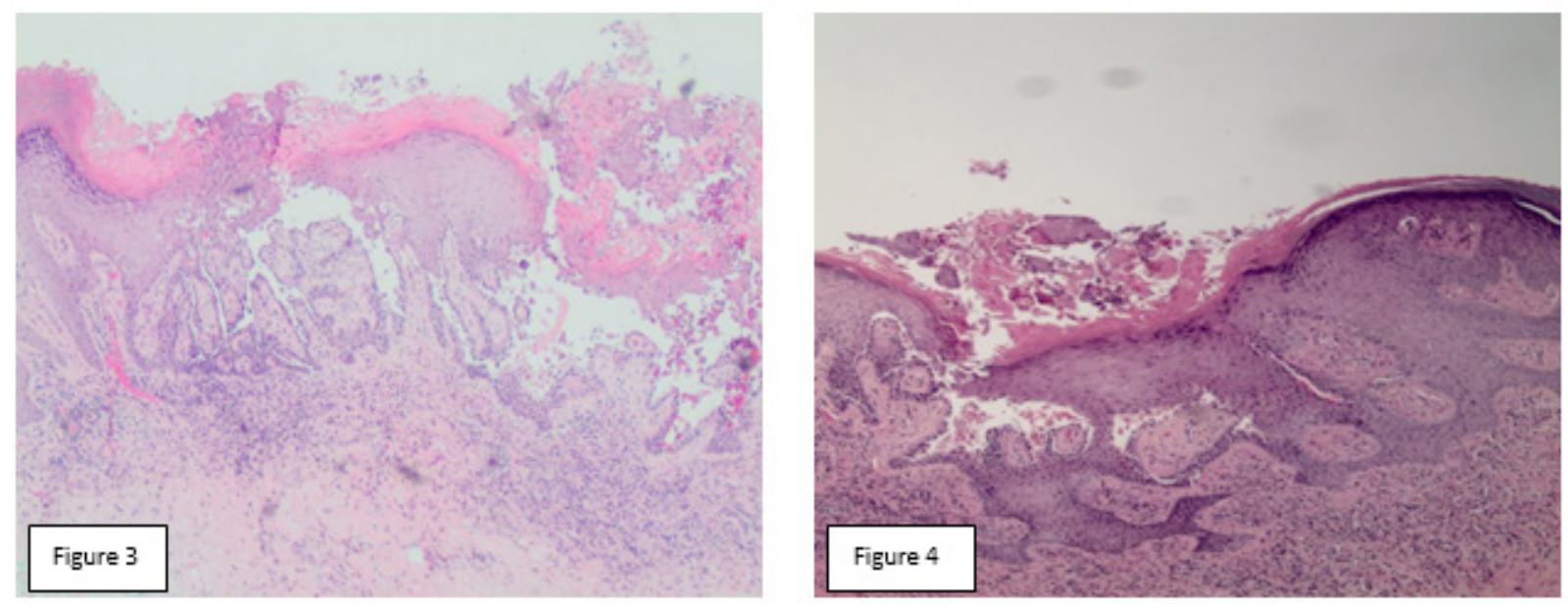

Figure 3 \& 4: Hematoxylin-eosin stain slides at 10X, showing acantholysis with dyskeratotic keratinocytes and background chronic inflammation.

The histologic findings of acantholysis and dyskeratosis can be seen in other cutaneous disorders include including Darier's disease, Hailey-Hailey disease and transient acantholytic dermatosis (Grover's disease) and Pemphigus Vulgaris. Hailey-Hailey disease demonstrates epidermal acantholysis, resembling a 'dilapidated brick wall appearance' and infrequent dyskeratosis. Darier disease has similar histopathologic findings of acantholytic dyskeratosis but usually presents clinically as verrucous papules and plaques in seborrheic regions, such as the flexures of the groin and axilla with characteristic nail changes. Both Hailey-Hailey disease and Dari- er's disease exhibit an autosomal dominant mutation in the calcium pump genes; ATP2C1 and ATP2A2; respectively, with a distinct personal and family history of recurrent lesions [4]. Transiennt acntholytic dermatosis (Grover's disease) shows suprabasal acantholysis with or without dyskeratosis and commonly occurring in middle aged to elderly patients, with multiple papulovesicular eruptions in a photo distributive pattern. Pemphigus vulgaris also shows acantholysis, typically in the spinous layer of the epidermis and is a well established autoimmune disorder presenting with flaccid blisters and positive direct immunofluorescence stain 
findings, including positive IgG and C3 immunoreactivity in the spinous epidermal layer. A PubMed search of "Acantholytic dermatosis of vulva" found 25 reported cases of this entity; which have been summarized in the table below (Table 1). In conclusion, careful assessment of the clinical presentation, course of disease, personal and family history play an important role alongside characteristic histopathological findings to make a definitive diagno- sis of acantholytic dyskeratosis. The pathogenesis still remains uncertain but a recent study implicated somatic mosaicism of the ATP2A2 mutation in multiple biopsies of acantholytic dyskeratosis lesions [6]. Dermatopathologists should be aware of this entity, as it can mimic other cutaneous disorders histologically with careful clinicopathologic correlation essential to correct diagnosis and appropriate treatment and management.

Table 1: Acantholytic dermatosis of vulva found 25 reported cases of this entity.

\begin{tabular}{|c|c|c|c|}
\hline $\begin{array}{l}\text { Published Cases of Acantholytic Dermatosis of } \\
\text { Vulva }\end{array}$ & Presentation & Age & Family History \\
\hline $\begin{array}{l}\text { Mansura A, Maly A, Ramot Y, Zlotogorski A } \\
2015 \text { [ 7] }\end{array}$ & Papular pruritic eruption & - & Negative \\
\hline $\begin{array}{l}\text { Elena Hadjicharralambous, Stephanie Diamond, } \\
2017[8]\end{array}$ & - & - & Questionable \\
\hline García-Morales I, Requena-Caballero L,2018 [9] & Ulcerated lesion & infant & Negative \\
\hline Yu WY, Ng E, Hale C,2016 [10] & - & - & $\begin{array}{l}\text { Familial hailey-hailey } \\
\text { disease }\end{array}$ \\
\hline Wong KT, Wong KK 1994 [11] & Warty lesion & 22 & Negative \\
\hline Cooper PH 1989 (6 cases reported) [12] & Multiple papules, solitary papules, and plaques & - & - \\
\hline Baliu-Piqué C, Iranzo P 2017 [13] & - & - & - \\
\hline $\begin{array}{l}\text { Haddadeen C, Theaker J, Rowen D, Lotery H } 2020 \\
{[14]}\end{array}$ & Erosive, scarring lesion; chronic & - & Negative \\
\hline $\begin{array}{l}\text { Dittmer CJ, Hornemann A, Rose C, Diedrich K, Thill } \\
\text { M } 2010 \text { [15] }\end{array}$ & Multiple papules, chronic & 45 & Negative \\
\hline Flores-Terry MA, Zamberk Majlis P 2017 [16] & Whitish papules and erosion & 30 & Negative \\
\hline Bell HK. 2001 (2 patients) [17] & Asymptomatic, popular lesion & - & Negative \\
\hline Sáenz AM, Cirocco A 2005 [18] & Pruritic popular eruption; chronic & 11 & Negative \\
\hline Lee S, 1989 [19] & Multiple papules & 32 & Negative \\
\hline Roh MR, Choi Y], Lee KG 2009 [20] & Asymptomatic popular eruption & 63 & Negative \\
\hline Wang L, Yang XC, Hao F, Mei Y, Ye QY 2009 [21] & - & - & - \\
\hline Peştereli HE 2000 [22] & Pruritic papule, chronic & 44 & Negative \\
\hline Van Joost T 1991 [23] & Pruritic, persistent eruption on chest and vulva & 35 & Negative \\
\hline Weedon D 1986 [24] & - & - & - \\
\hline Chorzelski TP 1984[25] & Multiple, whitish-grouped papules & 23 & Negative \\
\hline
\end{tabular}

\section{References}

1. Alina Goldenberg, Robert A. Lee, and Philip R (2014) Cohen Acantholytic dyskeratotic acanthoma: case report and review of the literature. Dermatol Pract Concept 4(3): 25-30.

2. Kentley J, Cerio R, Khorshid M, Gibbon K (2017) Acantholytic Dermatosis of the Vagina: The Diagnostic Challenge of Acantholytic Disease in the Genital Region. Clin Exp Dermatol 42(2): 189-191.

3. Margaret L, Leah H Ansell, Sameera Husain, Marc E, Grossman (2016) Papular acantholytic dyskeratosis of the genitocrural area: A rare unilateral asymptomatic intertrigo JAAD Case Rep. 2(2): 132-134.
4. Montis Palos, Acebo Mariñas E, Catón Santarén Soloeta Arechavala Papular Acantholytic Dermatosis in the Genito-Crural Region: A Localized Form of Darier Disease or Hailey-Hailey Disease? Actas Dermosifiliogr 104(2): 170-172.

5. Dittmer CJ, Hornemann A, Rose C, Diedrich K, Thill M (2010) Successful laser therapy of a papular acantholytic dyskeratosis of the vulva: case report and review of the literature. Arch Gynecol Obstet 281(4): 723725.

6. Eleanor A Knopp , Corey Saraceni, Jeremy Moss, Jennifer M McNiff, Keith A (2015) Somatic ATP2A2 Mutation in a Case of Papular Acantholytic Dyskeratosis: Mosaic Darier Disease. J Cutan Pathol 42(11): 853-857. 
7. Mansura A, Maly A, Ramot Y, Zlotogorski A (2015) Acantholytic Dermatosis of the Vulva. Dermatol Online J 21(5): 13030.

8. Elena Hadjicharralambous, Stephanie Diamond, David Mehregan (2017) Papular Acantholytic Dyskeratosis of Vulva in Setting of Hailey-Hailey 56(6): e126-e128.

9. García Morales I, Requena Caballero L, Happle R, Torrelo A (2018) Segmental Hailey-Hailey disease of the vulva. Pediatr Dermatol 35(6): e398-e399.

10. Yu WY, Ng E, Hale C, Hu S, Pomeranz MK (2016) Papular Acantholytic Dyskeratosis of the Vulva Associated with Familial Hailey-Hailey Disease Clin Exp Dermatol 41(6): 628-631.

11. Wong KT, Wong KK (1994)A case of acantholytic dermatosis of the vulva with features of pemphigus vegetans. J Cutan Pathol 21(5): 453-456.

12. Cooper PH (1989) Acantholytic dermatosis localized to the vulvocrural area.J Cutan Pathol 16(2): 81-84.

13. Baliu Piqué C, Iranzo P (2017) Papular Acantholytic Dyskeratosis of the Vulva in a Woman with Benign Familial Pemphigus.Actas Dermosifiliogr 108(1): 78-79.

14. Haddadeen C, Theaker J, Rowen D, Lotery H (2020) Acantholytic dyskeratosis of the vulva presenting with clinical features of vulval lichen sclerosus-A possible rare collision entity. J Cutan Pathol 47(1): 61-64.

15. Dittmer CJ, Hornemann A, Rose C, Diedrich K, Thill M (2010) Successful laser therapy of a papular acantholytic dyskeratosis of the vulva: case report and review of the literature. Arch Gynecol Obstet 281(4): 723725.

16. Flores Terry MA, Zamberk Majlis P, Franco Muñoz M, Vera Iglesias
E, García Arpa M, et al. (2017) Dermatosis papular acantolítica de la vulva con buena respuesta a tacrólimus tópico. Dermatol Online J 23(4):13030.

17. Bell HK, Farrar CW, Curley RK (2001) Papular acantholytic dyskeratosis of the vulva. Clin Exp Dermatol 26(5): 386-388.

18. Sáenz AM, Cirocco A, Avendaño M, González F, Sardi JR (2005) Papular acantholytic dyskeratosis of the vulva. Pediatr Dermatol 22(3): 237239.

19. Lee SH, Jang JG (1989) Papular acantholytic dyskeratosis of the genitalia. J Dermatol. 16(4): 312-314.

20. Roh MR, Choi YJ, Lee KG (2009) Papular acantholytic dyskeratosis of the vulva. J Dermatol 36(7): 427-429.

21. Wang L, Yang XC, Hao F, Mei Y, Ye QY (2009) Papular acantholytic dyskeratosis of the vulva. Eur J Dermatol 19(4): 402-403.

22. Peștereli HE, Karaveli S, Oztekin S, Zorlu G (2000) Benign persistent papular acantholytic and dyskeratotic eruption of the vulva: a case report. Int J Gynecol Pathol 19(4): 374-376.

23. Van Joost T, Vuzevski VD, Tank B, Menke HE (1991) Benign persistent papular acantholytic and dyskeratotic eruption: a case report and review of the literature.Br J Dermatol 124(1): 92-95.

24. Weedon D (1986) Papular acantholytic dyskeratosis of vulva..Am J Dermatopathol 8(4): 363.

25. Chorzelski TP, Kudejko J, Jablonska S (1984) Is papular acantholytic dyskeratosis of the vulva a new entity?Am J Dermatopathol 6(6): 557 560.

\section{Your next submission with Juniper Publishers} will reach you the below assets

- Quality Editorial service

- Swift Peer Review

- Reprints availability

- E-prints Service

- Manuscript Podcast for convenient understanding

- Global attainment for your research

- Manuscript accessibility in different formats

( Pdf, E-pub, Full Text, Audio)

- Unceasing customer service

\section{Track the below URL for one-step submission}

https://juniperpublishers.com/online-submission.php 